\title{
The Causes of Rising Australian Household Debt
}

\author{
Xianming Meng, Mahinda Siriwardana, and Judith McNeill
}

\begin{abstract}
Household debt in Australia has accelerated at an astonishing rate since the early 1990s. Discussions and arguments about household debt have been heated. More recently, the financial crisis in the US and the global economic recession seem to have declared the riskiness of uncontrolled household debt and thus silenced the argument. However, questions about the reasons for and the impact of rising Australian household debt still warrant comprehensive analysis. By employing macroeconomic data and the data from Australian household accounts, this paper identifies the features of Australian household debt and analyses the causes and effects of rising Australian household debt.
\end{abstract}

Index Terms-Australian household debt, housing investment, finance, impact, risk.

\section{INTRODUCTION}

Australian household debt grew rapidly in the early 1990s and by the turn of the century Australians were amazed by the acceleration in debt levels. This phenomenon has attracted enormous attention and discussions and arguments have been heated, both within and outside of Australia. On one hand, concern has been expressed about the rapid rise in Australian household debt. Others have taken a rather optimistic view. Reference [1] claimed that the financial position of Australian households was within a serviceable range according to the debt-service ratio and gearing ratio. However, this optimistic view was suppressed by bad news such as the US sub-prime crisis, the large write-downs announced by two of Australia's biggest banks and the world-wide economic recession. How serious is the Australian household debt problem? What are the reasons for and consequences of rising household debt? Answers to these questions seem more pertinent than ever. These questions are the central concerns addressed in this paper.

The remainder of the paper is organised as follows. The next section reviews the surveys and studies on Australian household debt. In Section II, we try to gain a comprehensive picture of Australian household debt. Section III discusses the reasons for rising Australian household debt respectively. Section IV concludes.

\section{LITERATURE REVIEW}

Prompted by rising Australian household debt, some institutions have included household debt information in their surveys or have initiated surveys on this topic. For example, the Australian Bureau of Statistics (ABS) has conducted a few

Manuscript received July 13, 2015; revised October 8, 2015.

Xianming Meng is with University of New England, Australia (e-mail: xmeng4@une.edu.au). waves of survey on Household Expenditure (HES), and it recently created the household balance sheet in the national accounts. Melbourne University started the Household, Income and Labour Dynamics in Australia (HILDA) Survey (funded by the federal government) in 2001 and has already completed 6 waves. The Reserve Bank of Australia (RBA) finished a survey in 2006 on Household Behaviour around Housing Equity. A number of studies at the household sector level have been based on these surveys: Reference [2] studied financial stress in Australia using the 1998-99 HES survey; Reference [3], by employing a logit model and using the data from the HES and HILDA surveys, studied the factors that affect financial constraints of Australian households. Reference [4] used a bivariate and logit model to analyse the data obtained by surveys on Household Behaviour around Housing Equity.

While the studies based on survey data provide information on household debt at the micro level, the RBA has published a number of papers and speeches at the macro level. For example, Reference [5] emphasized the positive effect of low inflation on household borrowings. The Reference [6] attributed the quick growth of personal credit to the innovations in products offered by banks, the increasing household preference towards the use of credit cards and the continuing economic expansion with low inflation and low interest rates. More recently, Reference [7] illustrated the composition and distribution of household debt and suggested that low interest rates, a low inflation rate, and financial deregulations may have led to the rising household debt. Other studies are similar in opinion to the RBA. For example, Reference [8] believed that financial deregulation, retailing credit, and new financial products and channels accounted for the rising household debt. Reference [9] suggested that the increase in household debt partly reflected increased house prices, thanks to the sustained low inflation and interest rates, and partly reflected the improved product choice and reductions in borrowing costs due to the deregulation of the financial sector in the 1980s and 1990s. Reference [1] claimed that rising household debt level is due to the sustained boom in house prices and the sustainability of household credit depends on the growth of household disposable income and employment. Reference [10] take a more Keynesian view since they argued that the government encouraged private spending and the growth of household debt in order to sustain Australia's economic growth.

All of these studies shed some light on different aspects of Australian household debt, but as far as is known, they have not investigated household accounts. So their conclusions would only be suggestive. Based on data from the household accounts, microeconomic data from surveys and other macroeconomic data, this study intends to provide a more comprehensive picture of Australian household debt. 


\section{FINANCIAL POSITION OF AUSTRALIAN HOUSEHOLD}

Household balance sheets provide an overall financial position. For example, the Treasury (2001) constructed a picture of household debt (see Fig. 1) by utilizing data from the household balance sheet, which shows that household liabilities increased from $\$ 250$ billion in June 1995 to $\$ 500$ billion in June 2001.

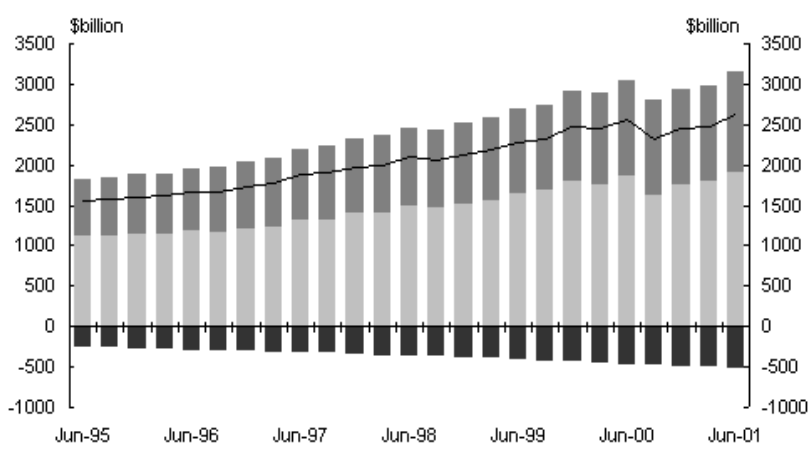

Non-financial assets _Linancial assets Liabilities _- Net wealth

Fig. 1. Australian household sector balance sheets. Source: The Treasury (2001).

International comparisons: by examining Australian household debt in the context of the world economy, we can better understand the financial position of Australian households. Fig. 2 depicts the household debt-income ratio in selected countries from 1984 through to 2004.

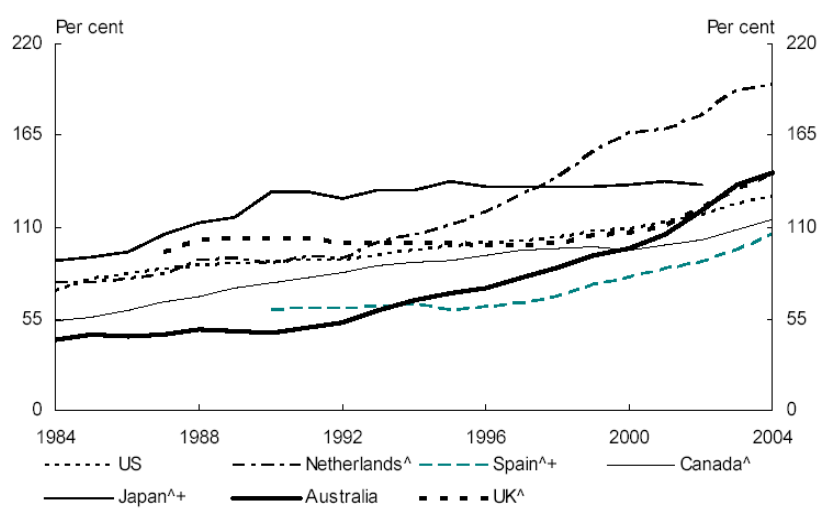

Fig. 2. Household debt to income ratio, selected countries. ${ }^{\wedge}$ Includes unincorporated enterprises.

+Income is after the deduction of interest payments. Source: RBA.

The selected countries in Fig. 2 all demonstrate upward trends in household debt-income ratios. Compared with other countries, Australian household debt, initially, was relatively low, but post 1990, increased at a similar pace to the escalation of household debt in the Netherlands. From 2000 onwards, the speed of growth is even higher than that of the Netherlands. As a result, the household debt level in Australia surpasses the US, Spain, and Canada, and ends up at the same level as the UK. One may feel some relief that Australia is not the country with the highest level of household debt, but the Netherlands has already shown economic problems (Reference [11]) and the housing bubble in the UK is a potential problem for its economy. An obvious warning sign can be drawn from Japan's experience. Japan has had consistently high levels of household debt for the last two decades and has suffered problems of an economic bubble since the 1980s.

From international comparisons of household debt-income ratios we can conclude that the Australian household debt level is potentially problematic. However, a comparison of household gearing ratios, as shown in Fig. 3, illustrates another aspect of Australian household debt.

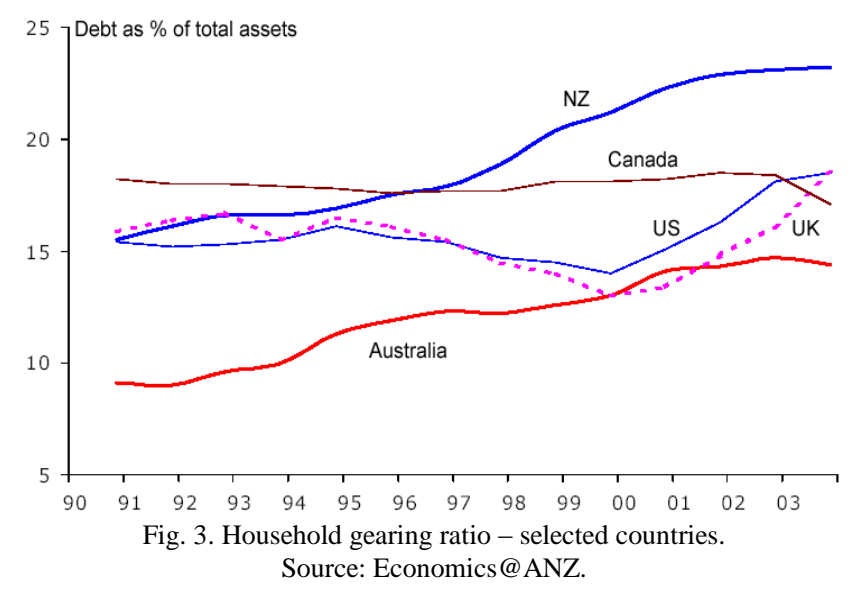

In Fig. 3, the gearing ratios fluctuate between $13 \%$ and $18 \%$ in Canada, the US, and the UK, while those in New Zealand and Australia demonstrate an apparent increasing trend. Among the selected five countries, the gearing ratio in Australia is the lowest. Why does Australia have a very high debt-income ratio but a low debt-asset ratio? Does the low debt-asset ratio mean Australian households are relatively safe and, potentially, have the capability of borrowing more? These are interesting questions worthy of exploration.

Comparisons with other sectors: because the magnitude of gross debt and of assets differs between different sectors, any comparison between them is better based on the net position of the sectors in relative terms. Fig. 4 demonstrates the changes in the different sectors' net positions over time.

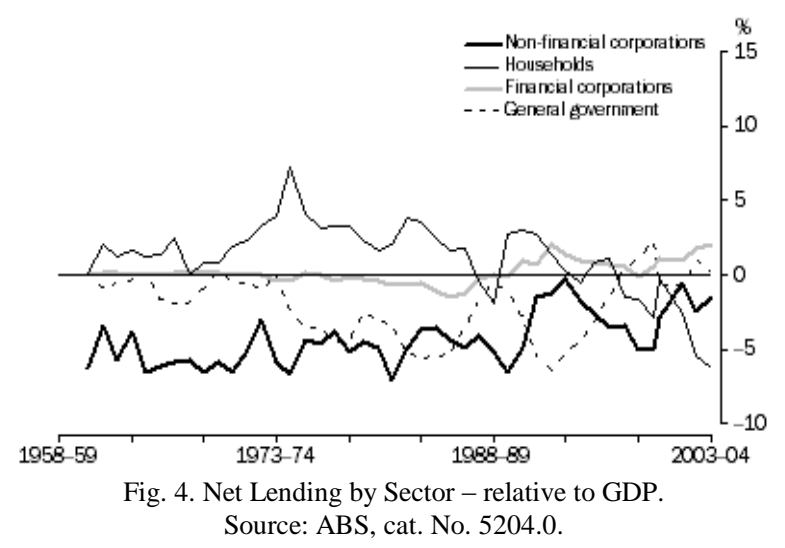

Prior to $1986-87$ the household sector in Australia was a net lender. From 1985-86 through to 1996-97 its net position changed several times. Since then it has been a net borrower, with borrowing increasing dramatically in recent times. Contrary to the household sector, the net position of the financial corporations sector changed in 1988-89 from net borrower to net lender. The non-financial corporations sector was a net borrower for the entire period as shown in Fig. 4 while the general government sector was also largely a net borrower. 


\section{CAuses of Rising Household DebT}

Based on the financial data of recent decades, this section purports to explore the factors that contribute to Australian household debt. They can be put into four categories; the increased credit supply, the changed household attitude towards borrowing, the favourable macroeconomic environment and beneficial government policies.

The increased credit supply

The supply of credit increased dramatically since the 1980s, which provided the possibility for Australian households to borrow more.

First, a large amount of "cheap" money was available globally. The easiness to obtain credit is indicated by the low interest rates across nations, shown in Fig. 7.
Fig. 7 indicates that world interest rates have fallen considerably from the high levels of the late 1980s. In most countries, official interest rates have fallen below 5\% since the late 1990s. A extreme case is Japan. Its interest rate has been close to zero since 1990. The low international interest rates since the early 1990s indicate that the money supply has increased around the world. Large sums of funds (e.g. enormous hedge funds in US) have flowed across countries seeking greater opportunities for profit. When these funds flowed to stock markets, they created financial bubbles; e.g. when they flowed into and out of Asia they caused the Asian financial crisis. When they flowed to global real estate markets, they led to housing bubbles. The increasing availability of funds increases the probability of a booming household debt market.

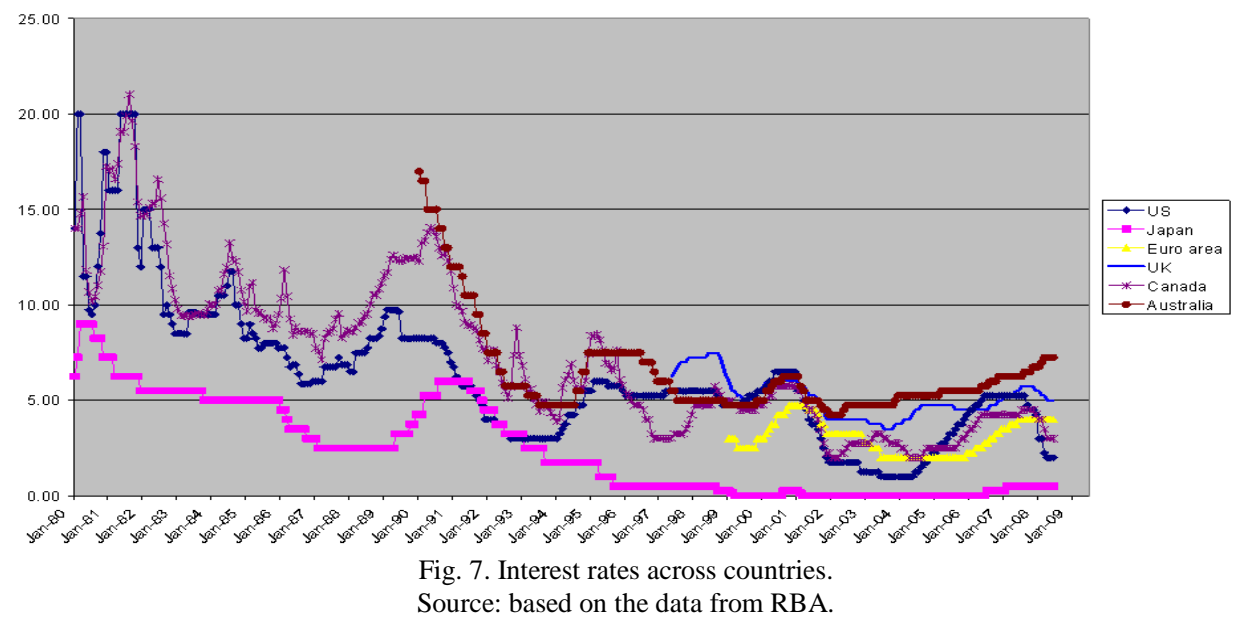

The relevance of increased world money supply with Australian household debt is manifested by the external balance of Australia, shown in Fig. 8.

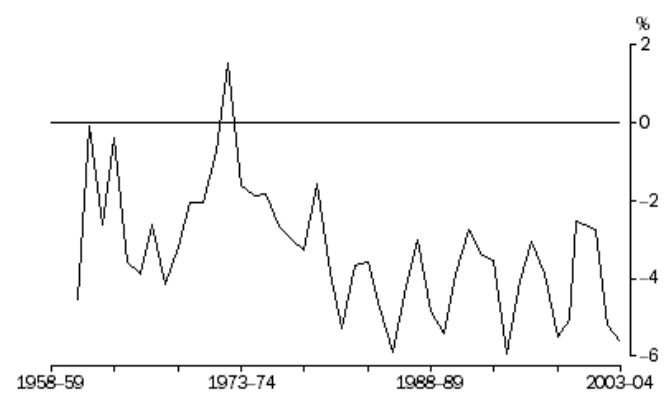

Fig. 8. Net Lending to Overseas - relative to GDP. Source: ABS, 5204.0.

Fig. 8 illustrates that, in aggregate, the domestic sector has been a net borrower over the past four to five decades. In 1979-80, net borrowing from overseas increased sharply from around $2 \%$ to $5 \%$. In subsequent years, it has fluctuated around $4 \%$. Net borrowing from overseas reached $5.6 \%$ in 2003-04, the highest ratio since 1994-95. Together with the information displayed in Fig. 4 that the main borrowers in recent years are households and non-financial corporations, we can conclude that some households may borrow indirectly from overseas.

Second, the Australian household sector itself is an important funding source. A glimpse of the household debt data in 2003-2004 convinces one of the important functions of this part of financial assets. The gross household debt increased by about $15 \%$ of GDP in the financial year 2003-2004 (calculated by author), but the household net borrowing from other sectors increased only around $6.3 \%$ of GDP at the same period (see Fig. 4). So, more than half of gross household debt is financed by households themselves. Obviously, it is most likely financed by household financial assets because of the difficulty involved in liquidation of non-financial assets.

The household financial account tells us that the main increase in household debt is in the form of loans and replacements while the main increase in Australian household financial assets is caused by insurance technical reserves and unfunded superannuation, shown in Fig. 9.

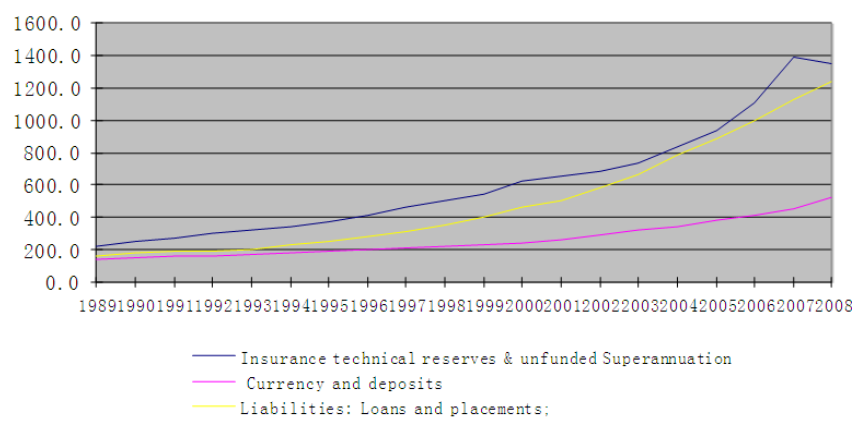

Fig. 9. Main household financial assets and liabilities (\$billion). Source: based on the data from RBA.

From Fig. 9 we know that the increase in household 
currency and deposits is very slow (only around 400 billion from 1989 to 2008). On the other hand, the insurance technique reserves and unfunded superannuation, the bulk of which is superannuation and pension funds, have increased remarkably (nearly 1200 billion from 1989 to 2007). As a result, the value of insurance technique reserves and unfunded superannuation has tripled during the period 1989-2007 and are about 2.5 times as much as that of currency and deposits held by households in recent years. The accelerated increase in superannuation can be explained by government policies. Legislation stipulates that companies must contribute a minimum $9 \%$ of wages to superannuation for each employee. The Government also has policies in place to encourage voluntarily employee contributions to super funds. These funds flow to and are reinvested by qualified financial institutions. Obviously, some will go to the household debt market because of the profitability in that market.

The changed attitude of households towards debt. In days gone by, Australians believed in "saving for rainy days", which was evident by the high level saving-ratio in the 1960s and 1970s. However, since the 1990s, the attitude of Australian households has changed.

First, Australian households have become more confident to borrow since the 1990s. With plenty of funds available for borrowing, the speed of increase in household debt is largely dependent on the household's willingness to borrow. Household's increased willingness to borrow can be shown by the annual incurred debt associated with their annual income. We have plotted Australian household gross disposable income (GDI) and household financial liabilities incurred per financial year from 1991 to 2006 in Fig. 10. The data are from the Australian household income and financial accounts.

Fig. 10 generally demonstrates a positive relationship between GDI and DEBT which indicates the importance of household income in decisions on borrowing. Before 1994, the annual borrowing is fairly small. But there are two jumps in household borrowing, one in 1994 and the other in 1998. After 2001, annual household borrowing increased tremendously. The increased slope since 2001 indicates that households are more willing to borrow than ever. The graph also displays another interesting feature: in an adverse economic environment, households respond by decreasing their borrowing, for example, in 2001 (911 events) and in 1997 (Asian Financial Crisis). The sensitiveness of household borrowing to the macroeconomic environment implies the significant role of economic performance, which will be discussed later.

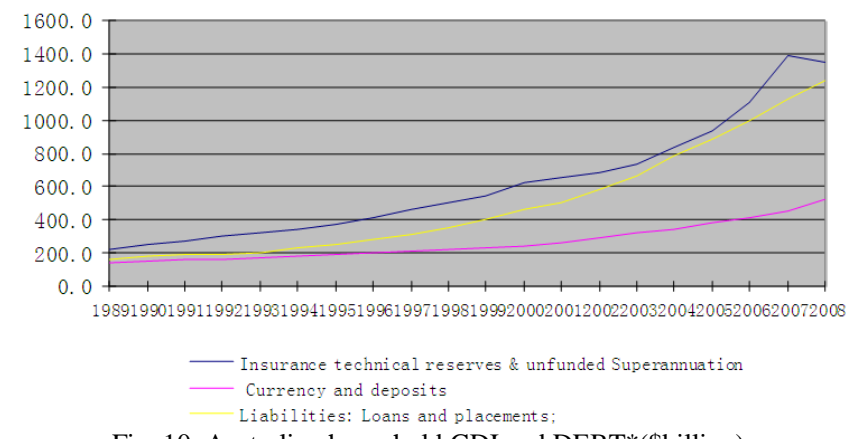

Fig. 10. Australian household GDI and DEBT*(\$billion).

*Note: the debt means the incurred debt in corresponding financial year, not total debt position.

Source: based on the data from ABS.

Second, debt-financed consumption becomes a fashion. According to the Life Cycle and Permenant Income Hypothesis (see Modigliani and Brumberg, 1954; Friedman, 1957), when people are relatively young and have lower income, they tend to borrow against their higher future income in order to smooth consumption. So financing consumption is an important motive of household borrowing This motive seems to be supported by household disposable income and consumption data, shown in Fig. 11.

Fig. 11 shows that disposable income and consumption both increase over time and accelerate rapidly after the late 1970s. It also shows that both household disposable income and consumption are very closely linked to each other. Before 1973, they are almost the same. After that, income grows faster, so the gap between them increases. However, since the late 1990s consumption by Australian households has increased faster than disposable income, so the gap decreased. From 2002, consumption dominates income and the reversed gap increases. This peculiar change may imply the emergence of a new pattern in consumption - borrowing-financed consumption.

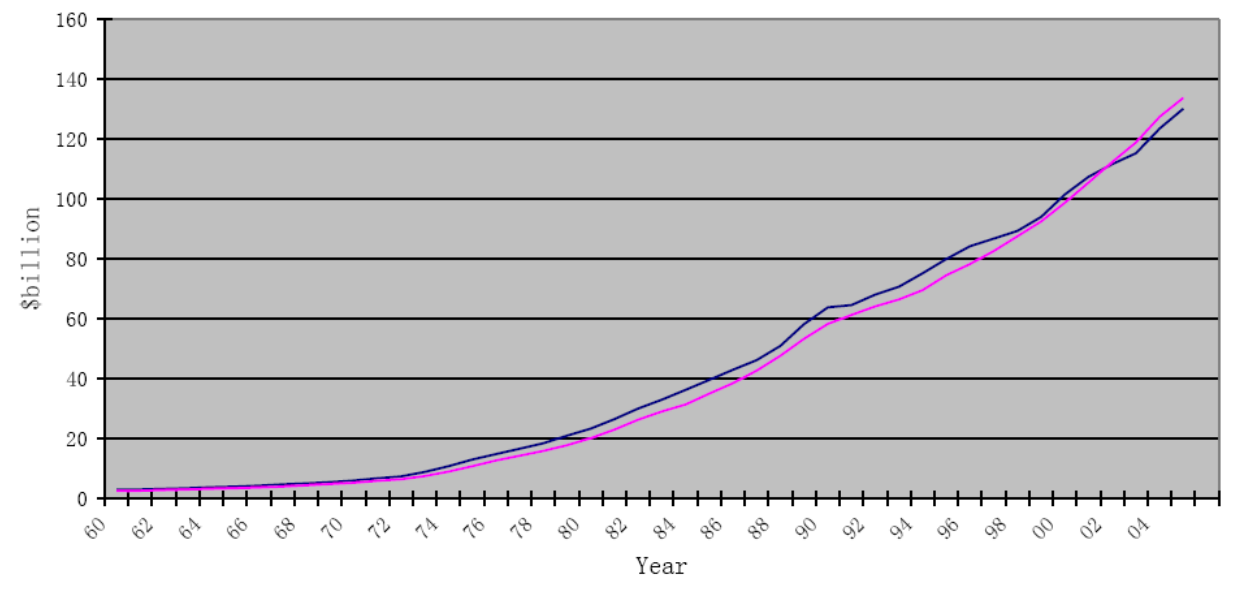

net dispossable income - final consumption

Fig. 11. Net disposable income and final consumption of Australian households Source: based on the data from ABS. 


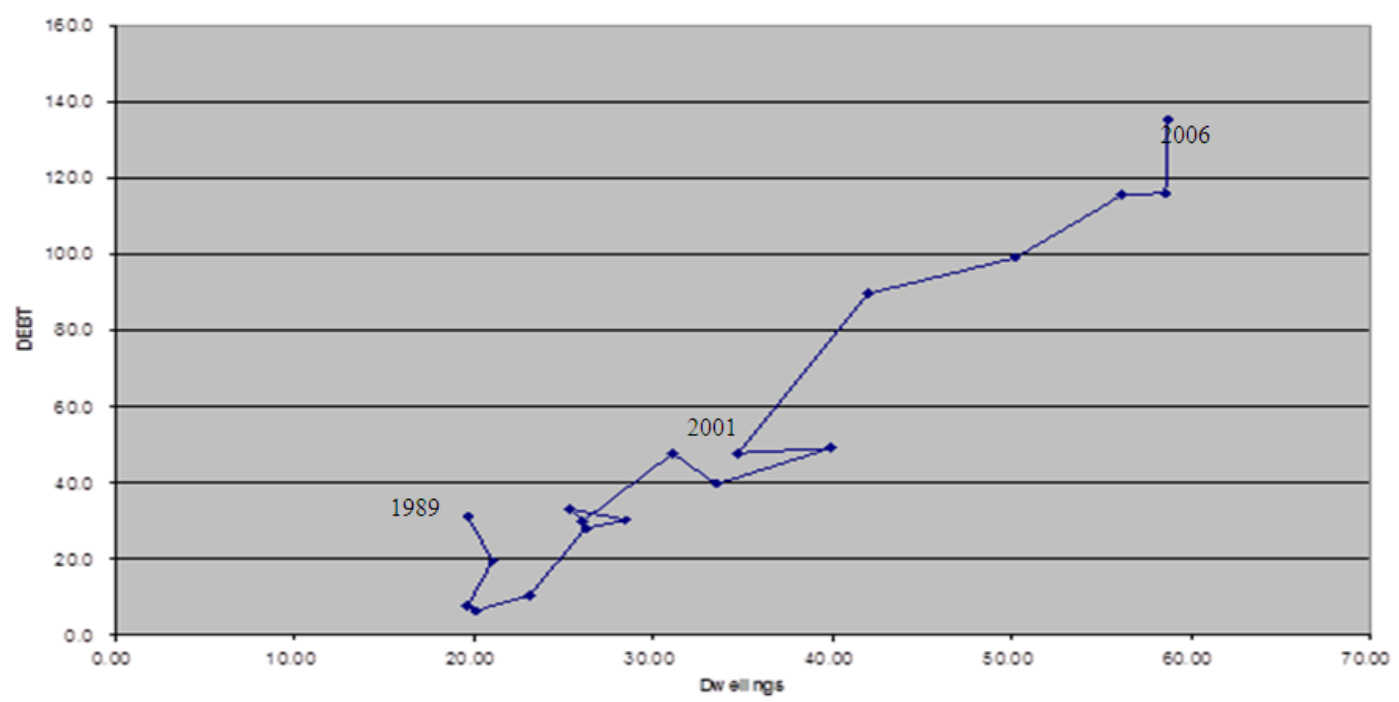

Fig. 12. Increase in household liabilities and dwelling assets

Note: the Debt and Dwellings value are incurred in each financial year, not accumulated position Source: based on the data from RBA.

Third, borrowing to invest becomes popular among Australian households. Australian households not only borrow to smooth consumption, but also borrow to finance investment. Housing has become their favourite investment vehicle in recent decades. In the 1960s, the most important non-financial assets were machinery and equipment, livestock, and dwellings. Livestock assets dominated the other non-financial assets. Although all acquisitions increase over time, the acquisitions of dwellings have increased to such an extent that, in June 2006, they totalled \$58,663 million, which is nearly 8 times that of livestock acquisitions (\$7,969 million) and more than 3 times that of machinery and equipment acquisitions ( $\$ 16,960$ million). Part of this dramatic increase in acquisitions of dwellings are debt-financed, which has already been confirmed in our decomposition of Australian household debt - housing mortgage debt is the majority of household liability as shown in Fig. 5. To further explore this relationship between household debt and housing assets, we graph the annual incurrence of liabilities against annual dwelling acquisitions in the period from June 1989 to June 2006, shown in Fig. 12.

Fig. 12 largely confirms our reasoning - the incurrence of debt is largely positively associated with housing assets. However, there are a number of other features worth noting. One is that before 1993 (the point with lowest incurrence of liabilities) the incurrence of debt decreases while dwelling acquisitions fluctuate between $\$ 19.5$ billions and $\$ 20$ billions. From this we can infer that, at that time, buying housing was not an influential factor for households to incur debt. Another feature is that, although the general trend is that the incurrence of debt goes up as dwelling acquisitions increase, from 1993 to 2001 , there are considerable variations between this positive relationship, which indicate other reasons for households' to incur debt. Third, from 2001 onwards, the positive relationship between the incurred debt and dwelling acquisitions is apparent, which strongly suggests that to obtain dwelling assets is an important motive for households incurring debt in recent years.

The favorite macroeconomic environment: The macroeconomic environment has great influence on economic agents, so it inevitably affects household debt, which is a result of the behavior of economic agents. There are many economic variables that indicate the macroeconomic situation. For Australian household debt, GDP, CPI, housing prices, interest rates and the unemployment rate are of most importance.

First, good Economic prospects indicated by the growth of GDP boost the optimistic expectations on household future income and thus confidence in lending and borrowing. Although economic recessions have occurred in other countries throughout the 1990s (e.g. 1997 Asian financial crisis) and in the new century (the 2001 economic recession in USA), the Australian economy has been largely exempt from these worries, enjoying relatively stable economic growth. The growth of GDP from 1992 to 2006 is shown in Fig. 13.

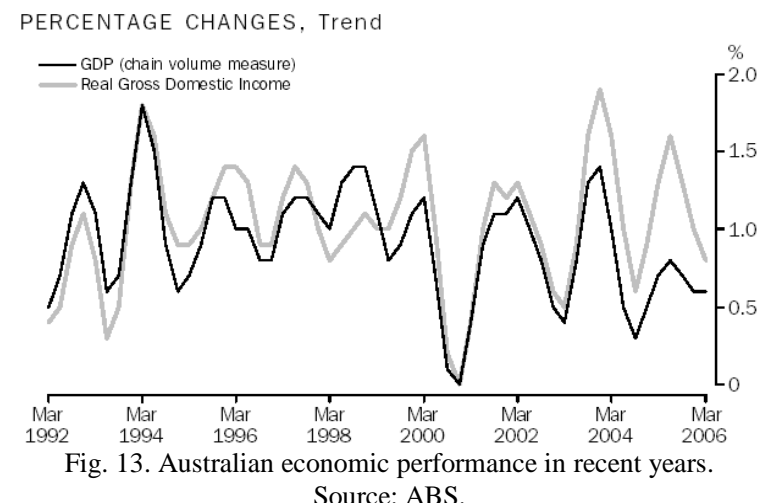

Fig. 13 shows the growth rate of GDP fluctuated around $1 \%$. There is a significant drop in 2001, but it is still positive. The long economic expansion (although the growth rate is not high) brought about optimistic expectations of the Australian economy. In this optimistic atmosphere, households expected higher future income, so it is justifiable for them to borrow more. On the other hand, lenders are less concerned about the credit risk (people are less likely to defer in economic boom than in economic recession) and tend to provide more credit.

Secondly, inflation and rising housing prices stimulate households' motives to acquire physical assets, especially, housing assets. Inflation encourages people to spend "hot" money to buy assets that maintain value or even to borrow to obtain physical assets. The persistent inflation since 1988 (see 
Fig. 14) justifies the households' motive to acquire assets. Due to various reasons such as the increasing population and government policy (it will be explained later), Australian households seem to favor housing assets. In Fig. 14 we see that the housing prices rose significantly during 1988-1991 and 1998-2006. Rising housing prices tend to encourage the expectation that they will continue to rise in the future and thus encourage more households into the housing mortgage market.

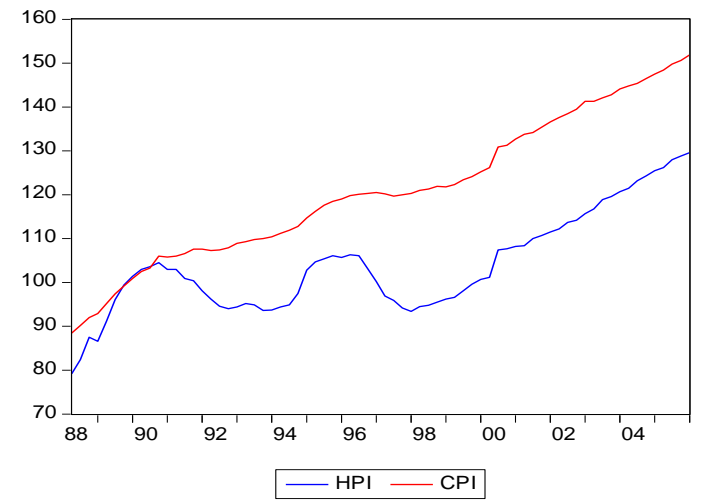

Fig. 14. The consumer price index (CPI) and housing price index (HPI) in Australia.

Source: ABS.

Third, low interest rates reduced the borrowing cost and the low unemployment rate eased credit constraint for households. The low official interest rate in Australia is demonstrated in Fig. 7 and the effect of low interest rates on household borrowing cost can be manifested by the debt-service ratio. According to the RBA (Macfarlane, 2003) the debt-service ratio is the interest paid by households as a percentage of disposable income. It indicates the relative borrowing cost with respect to income. The debt-service ratio of Australian households over time is shown in Fig. 15.

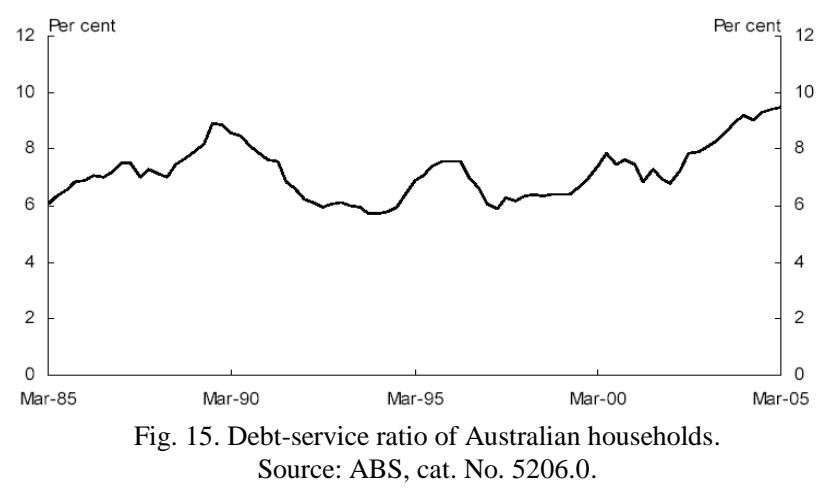

Fig. 15 tells us households' interest payment burden is between $6 \%$ to nearly $10 \%$ of their disposable income in the period from March 1985 to March 2005. The highest interest payment was experienced both at the end of the 1980s and in 2005, but the reasons are different. The former mainly reflected the high mortgage rates (averaged at $15 \%$ in the second half of 1980s) and the latter reflected the increase in the household debt level relative to income because mortgage rates dropped to around $7 \%$ in the $21^{\text {st }}$ century. The Fig. displays no time trend, which may indicate that the effect of the rise of the household debt level and that of the drop in the mortgage rates largely cancelled each other out.

The trend of the unemployment rate in Australia is shown in Fig. 16. It is apparent that the unemployment rate has a declining trend since 1992. In 2005 it was as low as 5\% (only slightly higher than the nature rate of unemployment rate).

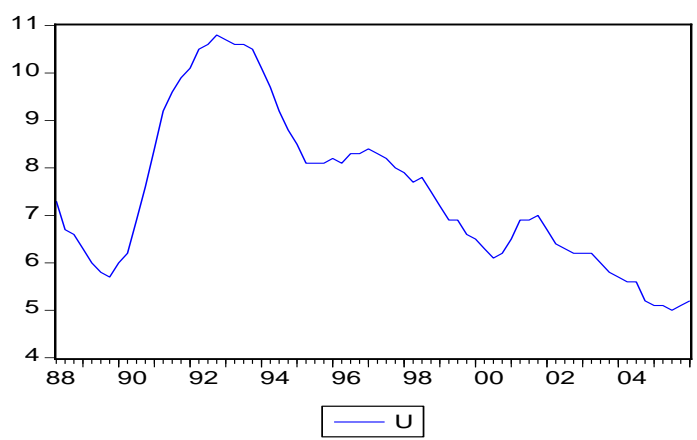

Fig. 16 the unemployment rate in Australia since 1988. Source: ABS

The low unemployment rate in recent years has important implications for household debt due to its influence on current and expected future household income. The expected future income is the base for borrowing and lending in the household debt market. If a person is currently unemployed, he/she has no income now and can hardly expect any income in the future. Concerned about his/her ability to pay back the loan, he/she is less likely to borrow. On the lending side, lenders are concerned very much about the safety of the loan. To reduce credit risk, lenders normally check the financial status and working history of the borrowers. The unemployment status means no ability to repay the loan so it puts a big question mark in the lender's mind.

The beneficial government policies: Government policy also plays an important role in the rapidly rising household debt in Australia. As we discussed earlier, superannuation policy may contribute positively to the increased funding of household debt. Other governmental policies which stimulate the growth of household debt are Australian financial deregulations and the compensation package introduced with the New Tax System.

We start with the financial deregulation. There were three deregulations on the mortgage market. Before deregulation, the financial institutions were highly regulated with the Government stipulating how much the institutions could lend and how high an interest rate they could charge. Under these regulations, financial institutions were reluctant to lend and therefore set very high lending criteria, making most people illegible for credit. Following the suggestion proposed by the "Campbell Inquiry", quantitative lending guidance was eliminated in 1982 and the ceilings on mortgage interest rates were removed in 1986. However, financial institutions were still highly regulated and there was little competition in the mortgage market. In 1996, the formal reform programme suggested by the Financial System Inquiry (the 'Wallis Inquiry') was in action and the number of financial institutions began to rise, substantially increasing competition in the mortgage market.

One effect of the intensified competition was that the financing costs dropped significantly. A good indicator of the financing cost is the lending margin (see Table I). From Table 4 we see that the lending margin reduced from $4.25 \%$ in 1993 to $1.8 \%$ in 2004 (the slight increase since 1999 may have resulted from the increased housing mortgage demand). 
TABLE I: LENDING MARGIN IN HOUSING MORTGAGE MARKET

\begin{tabular}{|l|l|l|l|}
\hline Year & $\begin{array}{l}\text { Official Rates } \\
(\%)\end{array}$ & $\begin{array}{l}\text { Standard Housing } \\
\text { Rate }(\%)\end{array}$ & $\begin{array}{l}\text { Difference } \\
(\text { Margin) }(\%)\end{array}$ \\
\hline 1993 & 5.25 & 9.50 & 4.25 \\
\hline 1994 & 4.75 & 8.75 & 4.00 \\
\hline 1995 & 7.50 & 10.50 & 3.00 \\
\hline 1996 & 7.50 & 9.75 & 2.25 \\
\hline 1997 & 5.50 & 7.20 & 1.70 \\
\hline 1998 & 5.00 & 6.70 & 1.70 \\
\hline 1999 & 4.75 & 6.55 & 1.80 \\
\hline 2000 & 6.00 & 7.80 & 1.80 \\
\hline 2001 & 5.00 & 6.80 & 1.80 \\
\hline 2002 & 4.72 & 6.55 & 1.83 \\
\hline 2003 & 4.75 & 6.55 & 1.80 \\
\hline 2004 & 5.25 & 7.05 & 1.80 \\
\hline
\end{tabular}

Another effect of intensified competition in the mortgage market was that the loan suppliers had to lose some constraints on mortgage loans to attract more households. The decreased borrowing requirement allowed more people to become eligible for borrowing. However, due to the intensified competition in the mortgage market, the financial institutions began to seek some ineligible households as their clients. Some lenders offered loans to borrowers with little documentation of saving or employment. On the other hand, the households with low income are seeking any possible financial institutions that can provide loans to them, since their condition did not qualify them for standard mortgage loan criteria. With both sides willing to decrease or even ignore the loan criteria, many unqualified loans (non-conforming loans) occurred in the mortgage market.

We turn to the government compensation package initiated in 1996. The Australian federal government introduced a New Tax System in 1996. The main reform was the introduction of the goods and services tax (GST). To ease the financial burden on households from the introduction of the GST, the government also introduced a number of associated policies such as a compensation package entitling first-home buyers to a governmental grant of $\mathrm{A} \$ 7,000$ and tax exemptions on imputed rental income and capital gains on sales for owner-occupied property. For investment housing, expenses such as interest and depreciation were tax deductible; tax on these investments can be deducted against other income; and capital gains on selling investment housing are taxed at half the taxpayer's marginal tax rate. All these policies tend to reduce the cost of home ownership, and thus encourage households to take on more debt in order to acquire housing assets.

\section{CONCLUSIONS}

The causes of rapidly rising household debt in Australia can be put in four categories: the increased credit supply, changed household attitude towards borrowing, favourable macroeconomic environment and beneficial government policies. The long economic expansion, readily available cheap money globally and the rapid increase in superannuation funds made the rising household debt possible. This possibility was utilized by households to smooth consumption and made a profit through investment during the in Australia. Government policy also plays an important role. The three financial deregulations loosened lending control and reduced financing cost thus stimulated both lending and borrowing. The superannuation policy helped to provide funding for household debt; and the compensation package coming with the New Tax System encouraged households to incur housing debt.

\section{REFERENCES}

[1] ANZ bank, The Senate Economic References Committee Public Inquiry, 2005.

[2] J. Bray, Hardship in Australia: An Analysis of Financial Stress Indicators in the 1998-1999 Australian Bureau of Statistics Household Expenditure Survey, Department of Family and Community Services Occasional Paper No 4, 2001.

[3] G. Canner, K. Dynan, and W. Passmore, "Mortgage refinancing in 2001 and early 2002," Federal Reserve Bulletin, vol. 88, 12, pp. 469-481, 2002.

[4] C. Schwartz, T. Hampton, C. Lewis, and D. Norman, "A survey of housing equity withdrawal and injection in Australia," RBA Research Discussion Papers RDP 2006-08, 2006.

[5] G. Stevens, "Some observations on low inflation and household finances," Reserve Bank of Australia Bulletin, pp. 38-47, October 1997.

[6] RBA (Reserve Bank of Australia), "Consumer Credit and Household Finance," Reserve Bank of Australia Bulletin, 1999.

[7] RBA (Reserve Bank of Australia), "Household debt: What the data show," Reserve Bank Bulletin, March 2003.

[8] Australian Consumers' Association, Life and Debt. (2003). [Online]. Available: http://www.choice.com.au/printfriendly.aspx?ID=103715

[9] The Australian Treasury, the Household Balance Sheet in Australia. (2001). [Online]. Available: http://www.treasury.gov.au/documents/108/html/docshell.asp?URL=6 _house.asp

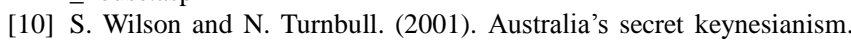
[Online].

Available: http://www.australianreview.net/digest/2000/08/wilson_turnbull.html

[11] G. Debelle, Household Debt and the Macro economy. BIS Quarterly Review, pp. 51-64, March 2004.

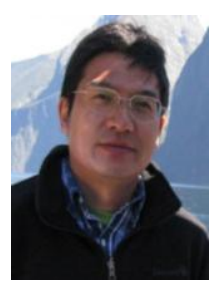

Xianming Meng is a senior research fellow at the Institute for Rural Futures and a lectureship at the UNE Business School, University of New England, Armidale, NSW 2351, Australia. His research interests include: environmental and resources modelling, tourism modelling, computable general equilibrium (CGE) modelling, time-series and panel data analysis, economic growth and fluctuation, financial economics. In recent years, he has published a number of papers in high quality academic journals such as Tourism Management, Tourism Analysis, Journal of Environmental and Resource Economics, Natural resources Research, and Asia Pacific Journal of Economics and Business. He currently works on a large environmental project - Australian Research Council (ARC) Linkage project: "Adaptation to Carbon-tax-induced Changes in Energy Demand in Rural and Regional Australia".

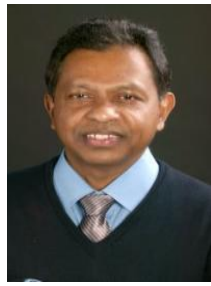

Mahinda Siriwardana is a professor of economics at UNE Business School, University of New England, Armidale. He received his $\mathrm{PhD}$ from $\mathrm{La}$ Trobe University in Melbourne. His main research interests include CGE modelling, trade policy analysis, and carbon price modelling. He has published seven books, and numerous journal articles in these fields. He is also a recipient of several Australian Research Council (ARC) Grants.

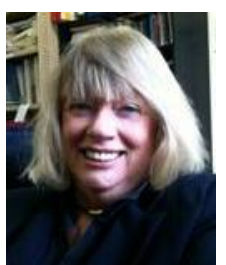

Judith McNeill is a senior research fellow in the Institute for Rural Futures, School of Behavioural, Cognitive and Social Sciences, at the University of New England. She is an economist with twenty years university teaching and research experience, and was formerly in the Australian public service in Canberra and Darwin. 